\title{
Red Blood Cell Alloimmunization with a Rare Antigen Causing a Delayed Hemolytic Transfusion Reaction in Sickle Cell Disease: A Case Report and Review of Management
}

Cassandra Wang ${ }^{1}$, Denise Malicki ${ }^{1}$, Courtney Thornburg ${ }^{1}$, Sonya Martinez ${ }^{2}$, and Jennifer $\mathrm{Yu}^{1}$

${ }^{1}$ University of California San Diego

${ }^{2}$ Rady Children's Hospital San Diego

November 16, 2020

\begin{abstract}
A delayed hemolytic transfusion reaction (DHTR) is a potential complication for patients with sickle cell disease (SCD) who develop red blood cell (RBC) alloimmunization to foreign antigens from allogeneic transfusions, resulting in life-threatening hemolytic anemia between 24 hours and 28 days after the transfusion. Guidelines have suggested obtaining an extended RBC antigen profile by genotyping in patients with SCD to provide increased accuracy for antigen matching. We present a pediatric patient with SCD and a rare RBC antigen genotype who developed DHTR to describe the significant challenges with antibody identification, the process of obtaining compatible blood, and our medical management.
\end{abstract}

\section{Hosted file}

DHTR Case Report Final.pdf available at https://authorea.com/users/375981/articles/493150red-blood-cell-alloimmunization-with-a-rare-antigen-causing-a-delayed-hemolytic-

transfusion-reaction-in-sickle-cell-disease-a-case-report-and-review-of-management

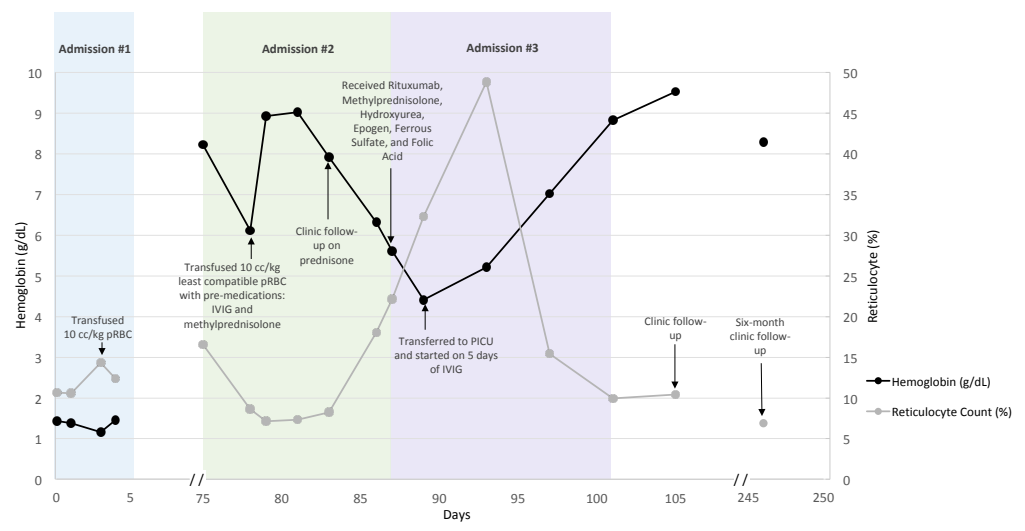

